Supporting Information

\title{
QM/MM Simulations of Protein Crystal Reactivity Guided by MSOX Crystallography: A Copper Nitrite Reductase Case Study
}

\author{
Kakali Sen ${ }^{\dagger \neq}$, Michael A. Hought, Richard W. Strange ${ }^{* \dagger}$, Chin Yongt, and Thomas W. Keal ${ }^{* *}$ \\ $\uparrow$ School of Life Sciences, University of Essex, Wivenhoe Park, Colchester, Essex, CO4 3SQ, \\ United Kingdom.
}

$\ddagger$ Scientific Computing Department, STFC Daresbury Laboratory, Keckwick Lane, Daresbury, Warrington, Cheshire, WA4 4AD, United Kingdom.

*Correspondence email: thomas.keal@stfc.ac.uk; r.strange@essex.ac.uk

\section{Contents}

\begin{tabular}{|c|c|c|}
\hline Table S1 & Geometric parameters for $\mathrm{NO}_{2}^{-}$bound to $\mathrm{T} 2 \mathrm{Cu}(\mathrm{II})$ in the crystal system & $\mathrm{S} 2$ \\
\hline Figure S1 & Optimised structures of $\mathrm{HNO}_{2}$ bound to $\mathrm{T} 2 \mathrm{Cu}$ (II) & $\mathrm{S} 2$ \\
\hline Figure S2 & All $\mathrm{NO}_{2}{ }^{-}$intermediates bound to $\mathrm{Cu}(\mathrm{I})$ found by $\mathrm{QM} / \mathrm{MM}$ calculations & S3 \\
\hline Table S2 & $\begin{array}{l}\text { Energies and geometries of all } \mathrm{NO}_{2}^{-} \text {intermediates bound to } \mathrm{Cu}(\mathrm{I}) \text { found by } \\
\mathrm{QM} / \mathrm{MM} \text { calculations }\end{array}$ & S3 \\
\hline Table S3 & $\begin{array}{l}\text { Absolute and relative potential energies of } \mathrm{Cu}(\mathrm{I})-\mathrm{NO}_{2}^{-} \text {intermediates with } \\
\text { different exchange-correlation density functionals. }\end{array}$ & $\mathrm{S} 4$ \\
\hline Figure S3 & $\begin{array}{l}\text { CI-NEB pathway pathways from monodentate top-hat to N-bound and reverse } \\
\text { side-on intermediates }\end{array}$ & $\mathrm{S} 4$ \\
\hline Table S4 & $\begin{array}{l}\text { Thermal and entropic corrections at } 190 \mathrm{~K} \text { to all the } \mathrm{NO}_{2}{ }^{-} \text {intermediates bound } \\
\text { to } \mathrm{Cu}(\mathrm{I}) \text { found by } \mathrm{QM} / \mathrm{MM} \text { calculations }\end{array}$ & S5 \\
\hline Figure S4 & $\begin{array}{l}\text { CI-NEB profiles of proton transfer to } \mathrm{NO}, \mathrm{OH}^{-} \text {bound intermediate in crystal } \\
\text { system formed from dissociation of } \mathrm{HNO}_{2} \text { intermediate on proton transfer } \\
\text { starting from side-on, reverse side-on and } \mathrm{N}_{-} \text {-bound } \mathrm{NO}_{2}^{-} \text {intermediates }\end{array}$ & S6 \\
\hline Figure S5 & $\begin{array}{l}\mathrm{HNO}_{2} \text { intermediates formed from monodentate top-hat } \mathrm{NO}_{2}^{-} \text {intermediate on } \\
\text { proton transfer in crystal system }\end{array}$ & S6 \\
\hline Table S5 & $\begin{array}{l}\text { Geometrical parameters for } \mathrm{NO}_{2}^{-} \text {bound to } \mathrm{T} 2 \mathrm{Cu} \text { in both oxidised } \mathrm{Cu}(\mathrm{II}) \text { and } \\
\text { reduced } \mathrm{Cu}(\mathrm{I}) \text { for all the six selected snapshots in the solvated Asp98p-Hsp } \\
\text { system }\end{array}$ & S7 \\
\hline Table S6 & $\begin{array}{l}\text { Absolute and relative } \mathrm{QM} / \mathrm{MM} \text { energies for the optimised } \mathrm{Cu}(\mathrm{I})-\mathrm{NO}_{2}{ }^{-} \\
\text {intermediates on the } 3 \text { subunits }(\mathrm{A}, \mathrm{B}, \mathrm{C}) \text { of snapshot (i) described in the } \\
\text { manuscript. }\end{array}$ & S8 \\
\hline Figure S6 & $\begin{array}{l}\text { Structures of all the } \mathrm{Cu}(\mathrm{I})-\mathrm{NO}_{2}{ }^{-} \text {intermediates in the } 2 \text { subunits } \mathrm{A} \text { and } \mathrm{C} \text { of } \\
\text { snapshot (i) described in the manuscript. }\end{array}$ & S9 \\
\hline Figure S7 & $\begin{array}{l}\text { CI-NEB profiles for conversion of } \mathrm{Cu}(\mathrm{I})-\mathrm{NO}_{2}{ }^{-} \text {monodentate top-hat intermediate } \\
\text { to side-on, reverse side-on and } \mathrm{N} \text {-bound intermediates in all subunits of snapshot } \\
\text { (i) described in the manuscript. }\end{array}$ & S9 \\
\hline Table S7 & $\begin{array}{l}\text { Geometric parameters for } \mathrm{NO}_{2}^{-} \text {bound to } \mathrm{T} 2 \mathrm{Cu} \text { in both oxidised } \mathrm{Cu}(\mathrm{II}) \text { and } \\
\text { reduced } \mathrm{Cu}(\mathrm{I}) \text { for all the selected snapshots in solvated Asp98p-Hsd and Asp98- } \\
\text { Hsp systems }\end{array}$ & S10 \\
\hline Figure S8 & $\begin{array}{l}\mathrm{HNO}_{2} \text { intermediates formed from side-on, reverse side-on and monodentate top- } \\
\text { hat } \mathrm{NO}_{2}^{-} \mathrm{Cu}(\mathrm{I}) \text { intermediates on proton transfer in the snapshot (i) described in } \\
\text { the manuscript. }\end{array}$ & S11 \\
\hline
\end{tabular}


Table S1. Calculated geometric parameters ${ }^{1}$ for the optimisation of $\mathrm{NO}_{2}{ }^{-}$bound to $\mathrm{Cu}(\mathrm{II})$ at the $\mathrm{T} 2 \mathrm{Cu}$ site starting from three initial MSOX crystalline states, for different protonation states of Asp CAT $_{\text {and Hiscat. }}$

\begin{tabular}{|l|l|l|l|}
\hline $\begin{array}{l}\text { Initial crystal } \\
\text { structure }\end{array}$ & Protonation state* & $\begin{array}{l}\text { Distances }(\AA) \\
\text { Cu-N, Cu-O1, Cu-O2 }\end{array}$ & $\theta, \psi\left(\right.$ degrees) ${ }^{1}$ \\
\hline Top-hat Conf-1 & Asp-Hsp & $2.61,2.36,2.02$ & $176.3,171.6$ \\
\hline & Asp98p-Hsd & $2.60,2.31,2.05$ & $180.0,174.2$ \\
\hline & Asp98pR-Hsd & $2.63,2.30,2.10$ & $175.6,174.4$ \\
\hline & Asp98p-Hsp & $2.58,2.32,2.02$ & $177.4,172.4$ \\
\hline & Asp98pR-Hsp & $2.62,2.32,2.08$ & $177.8,172.7$ \\
\hline Top-hat Conf-2 & Asp-Hsp & $2.59,2.032 .31$ & $179.5,173.0$ \\
\hline & Asp98p-Hsd & $2.60,2.05,2.31$ & $179.9,174.3$ \\
\hline & Asp98pR-Hsd & $2.62,2.10,2.30$ & $175.5,174.4$ \\
\hline & Asp98p-Hsp & $2.61,2.05,2.33$ & $179.6,172.9$ \\
\hline & Asp98pR-Hsp & $2.62,2.08,2.33$ & $178.0,172.6$ \\
\hline & Asp-Hsp & $2.59,2.02,2.31$ & $178.7,173.0$ \\
\hline & Asp98p-Hsd & $2.62,2.10,2.30$ & $174.1,174.1$ \\
\hline & Asp98pR-Hsd & $2.59,2.05,2.30$ & $180.0,174.3$ \\
\hline & Asp98p-Hsp & $2.63,2.09,2.32$ & $179.7,173.0$ \\
\hline & Asp98pR-Hsp & $2.60,2.03,2.33$ & $179.8,172.2$ \\
\hline
\end{tabular}

*Asp can be protonated on either of its $\mathrm{O}$ atoms (O1, O2). Asp98p and Asp98pR represent protonation of $\mathrm{O} 1$ and $\mathrm{O} 2$ of Asp respectively.

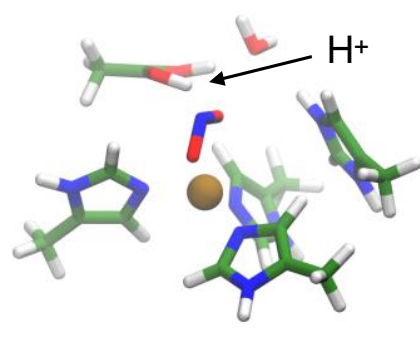

Asp98p-Hsp

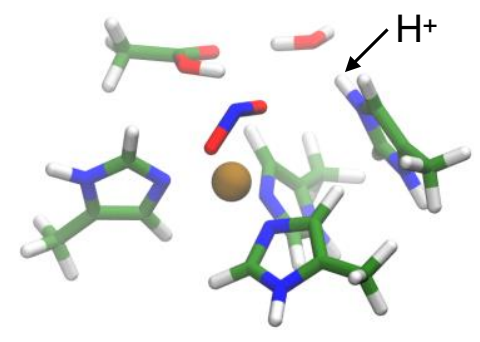

Asp98p-Hsd

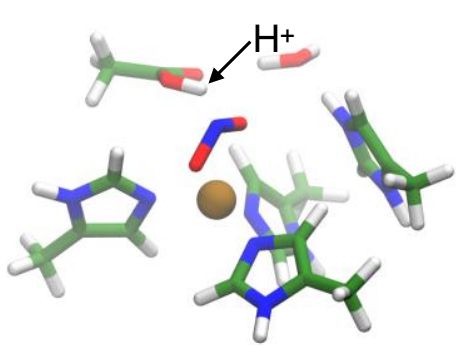

Asp98-Hsp

Figure S1. Optimised structures of the QM region starting from top-hat $\mathrm{HNO}_{2}$ bound to $\mathrm{T} 2 \mathrm{Cu}$ in its oxidised $\mathrm{Cu}$ (II) state. In these structures the top hat $\mathrm{NO}_{2}{ }^{-}$was protonated on the oxygen near to Asp СAт. Optimised structures for all the probable protonation states are provided. In case of Asp98p-Hsp, the $\mathrm{H}^{+}$from $\mathrm{HNO}_{2}$ sits on Asp molecule in the water channel. In Asp98p-Hsd, the proton from $\mathrm{HNO}_{2}$ is transferred to Asp

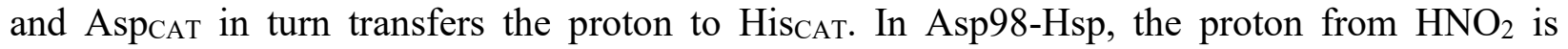
transferred to the Asp the top-hat $\mathrm{NO}_{2}^{-}$bound to $\mathrm{Cu}(\mathrm{II})$ state. A subset of active site residues is shown in the QM region for clarity. 


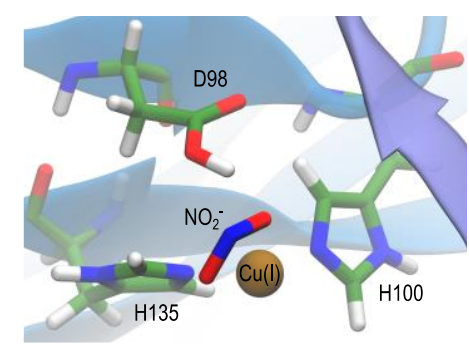

(A) Top-Hat Monodentate (0.0)
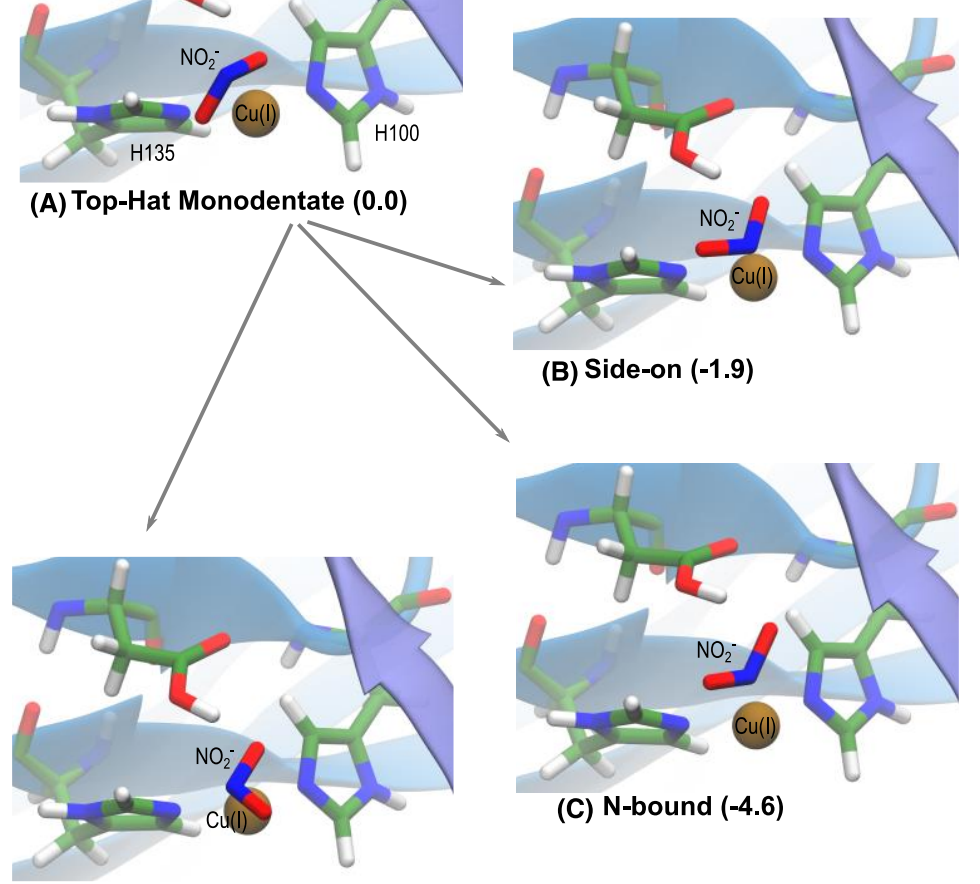

(B) Side-on (-1.9)

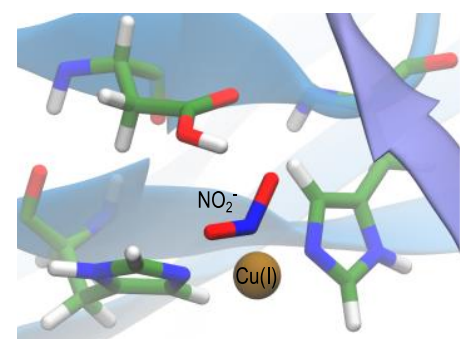

(C) N-bound (-4.6)

(D) Reverse side-on (-5.9)

Figure S2. All the intermediates with $\mathrm{NO}_{2}^{-}$bound to reduced $\mathrm{Cu}(\mathrm{I})$ found by $\mathrm{QM} / \mathrm{MM}$ calculations. The B3LYP-D3/def2-TZVP(Cu):def2-SVP(all):CHARMM energies in $\mathrm{kcal} / \mathrm{mol}$ relative to $\mathrm{Cu}(\mathrm{I})$ top-hat monodentate are given in parentheses.

Table S2. Energies and geometrical parameters for $\mathrm{NO}_{2}^{-}$bound to $\mathrm{T} 2 \mathrm{Cu}$ in the reduced $\mathrm{Cu}(\mathrm{I})$ state. The B3LYP-D3/def2-TZVP(Cu):def2-SVP(all):CHARMM energies (absolute and relative) of the intermediates are calculated with respect to the monodentate top-hat intermediate. The geometrical parameters $(\theta$ and $\psi)$ used in previous work to determine different geometric orientations in a three-domain $\mathrm{CuNiR}{ }^{1}$ are given in the table along with $\mathrm{Cu}-\mathrm{NO}_{2}{ }^{-}$distances. The clustering of the structures followed the range of $\theta$ and $\psi$, however, the azimuthal angle is not valid for side-on or reverse side-on geometries.

\begin{tabular}{|l|l|l|l|l|}
\hline $\mathrm{Cu}(\mathrm{I})$ intermediates & $\mathrm{E}($ Hartree $)$ & $\begin{array}{l}\Delta \mathrm{E} \\
(\mathrm{kcal} / \mathrm{mol})\end{array}$ & $\begin{array}{l}\text { Distances }(\AA) \\
\mathrm{Cu}-\mathrm{N}, \mathrm{Cu}-\mathrm{O} 1, \mathrm{Cu}-\mathrm{O} 2\end{array}$ & $\theta, \psi$ (degrees) \\
\hline $\begin{array}{l}\text { Monodentate top- } \\
\text { hat }\end{array}$ & -3488.1296 & 0.0 & $2.87,2.75,2.13$ & $173.6,167.1$ \\
\hline Side-on & -3488.1326 & -1.9 & $2.38,3.00,2.40$ & $76.5, \mathrm{n} / \mathrm{a}$ \\
\hline N-Bound & -3488.1370 & -4.6 & $1.99,2.80,2.85$ & $18.1,1.36$ \\
\hline Reverse side-on & -3488.1390 & -5.9 & $2.50,3.15,2.30$ & $83.1, \mathrm{n} / \mathrm{a}$ \\
\hline
\end{tabular}


Table S3: Absolute and relative potential energies of $\mathrm{Cu}(\mathrm{I})-\mathrm{NO}_{2}{ }^{-}$intermediates calculated with different exchange-correlation density functionals. Relative energies are measured relative to the top-hat monodentate intermediate.

\begin{tabular}{|l|l|l|l|l|}
\hline Intermediates & $\begin{array}{l}\text { Monodentate } \\
\text { top-hat }\end{array}$ & Side-on & N-Bound & $\begin{array}{l}\text { Reverse } \\
\text { side-on }\end{array}$ \\
\hline PBE: Absolute Energies (Hartree) & -3486.8141 & -3486.8196 & -3486.8218 & -3486.8228 \\
\hline PBE: $\Delta \mathrm{E}(\mathrm{kcal} / \mathrm{mol})$ & 0 & -3.4 & -5.5 & -4.8 \\
\hline $\begin{array}{l}\text { PBE0: Absolute Energies } \\
(\text { Hartree })\end{array}$ & -3486.9003 & -3486.9024 & -3486.9099 & -3486.9086 \\
\hline PBE0: $\Delta \mathrm{E}(\mathrm{kcal} / \mathrm{mol})$ & 0 & -1.4 & -5.2 & -6.0 \\
\hline $\begin{array}{l}\text { B2PLYP: Absolute Energies } \\
(\text { Hartree) }\end{array}$ & -3487.1359 & -3487.1389 & -3487.1446 & -3487.1436 \\
\hline B2PLYP: $\Delta \mathrm{E}(\mathrm{kcal} / \mathrm{mol})$ & 0 & -1.9 & -5.4 & -4.8 \\
\hline
\end{tabular}

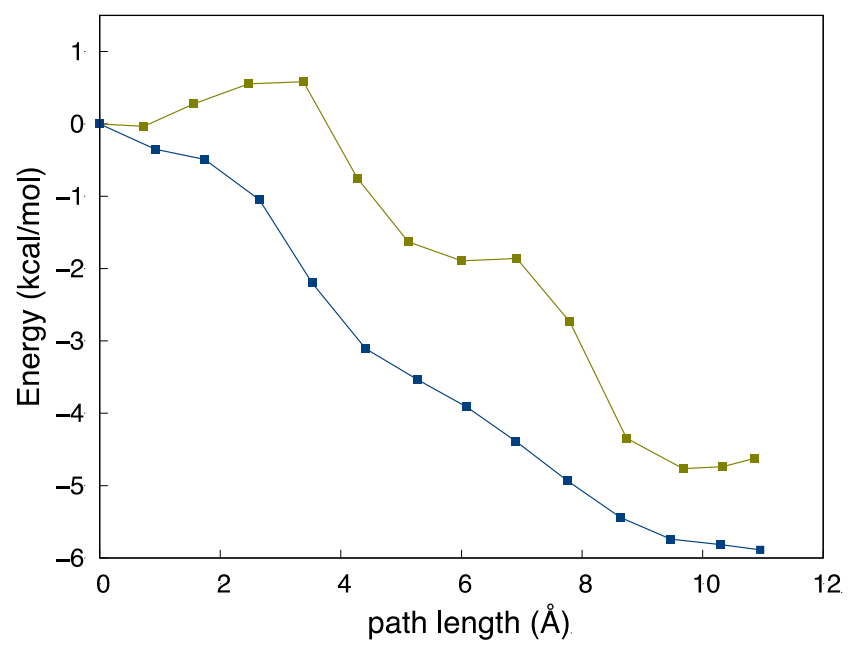

Figure S3. (a) CI-NEB pathway starting from monodentate top-hat intermediate to N-bound (green) and reverse side-on (blue). The results suggest that all the orientations are accessible from the monodentate top-hat structure, but as this is unambiguously ruled out by the experimental MSOX data, we conclude that these results reflect limitations of the DFT method used for modelling the QM region. 
Table S4: Thermal and entropic corrections at $190 \mathrm{~K}$ to B3LYP-D3/def2-TZVP(Cu):def2SVP(all):CHARMM potential energies of the intermediates. Relative energies where provided are measured relative to top-hat monodentate intermediate

\begin{tabular}{|l|l|l|l|l|}
\hline Intermediates & $\begin{array}{l}\text { Monodentate } \\
\text { top-hat }\end{array}$ & Side-on & N-Bound & $\begin{array}{l}\text { Reverse } \\
\text { side-on }\end{array}$ \\
\hline $\begin{array}{l}\text { Thermal corrections (Hartree) at } \\
190 \mathrm{~K}\end{array}$ & 5.6818 & 5.6811 & 5.6846 & 5.6822 \\
\hline $\begin{array}{l}\text { Absolute QM/MM energies } \\
\text { (Hartree) with thermal corrections } \\
\text { at } 190 \mathrm{~K}\end{array}$ & -3482.4478 & -3482.4515 & -3482.4523 & -3482.4568 \\
\hline $\begin{array}{l}\Delta \mathrm{E}(\mathrm{kcal} / \mathrm{mol}) \text { with thermal } \\
\text { corrections at 190 K }\end{array}$ & 0 & -2.3 & -2.8 & -5.6 \\
\hline $\begin{array}{l}\text { Temperature*Entropy } \\
\text { contributions (Hartree) at 190K } \\
{[-\mathrm{TS}]}\end{array}$ & -0.2727 & -0.2719 & -0.2710 & -0.2714 \\
\hline$-\Delta \mathrm{TS}$ (kcal/mol) & 0 & & & 0.8 \\
\hline
\end{tabular}

Nitric Oxide formation in crystalline $A c$ NiR from the Top-hat Monodentate, Reverse sideon and $\mathrm{N}$-Bound $\mathrm{NO}_{2}{ }^{-}$intermediates.

To explore reaction pathways from the other intermediates observed on the QM/MM potential energy surface we subjected the reverse side-on and $\mathrm{N}$-bound $\mathrm{Cu}(\mathrm{I})$ intermediates to the same procedure as the side-on intermediate to assess the feasibility of NO formation in all cases. The reverse side-on $\mathrm{NO}_{2}^{-}$complex proceeded in a similarly barrierless formation of $\mathrm{NO}$ and $\mathrm{OH}$ (Figure 6 in manuscript) and also provided a similar energy barrier [ $8.9 \mathrm{kcal} / \mathrm{mol}]$ for further proton transfer to form $\mathrm{NO}$ and $\mathrm{H}_{2} \mathrm{O}$ (Figure $\mathrm{S} 4$ below). $\mathrm{HNO}_{2}$ intermediates were observed when starting with either N-bound or monodentate intermediates; the $\mathrm{HNO}_{2}$ bound N-bound structure doesn't correspond to any observed MSOX intermediate, however, proton transfer from His $\mathrm{CAT}_{\mathrm{T}}$ to $\mathrm{OH}$ via

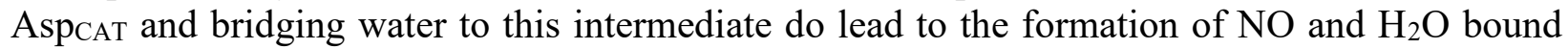
intermediate. It is a two-step process: initially forming the intermediate $\mathrm{NO}$ and $\mathrm{OH}$ with a low barrier of $\sim 2.0 \mathrm{kcal} / \mathrm{mol}$ (as observed for side-on and reverse side-on geometry, where the protonation of $\mathrm{Cu}(\mathrm{I})$ nitrite led to barrierless formation of the same intermediate) and then forming $\mathrm{NO}$ and $\mathrm{H}_{2} \mathrm{O}$ as obtained for side-on and reverse side-on intermediates but with a barrier of $\sim 4.7$ $\mathrm{kcal} / \mathrm{mol}$ (Figure S4 below). Proton transfer to the monodentate intermediate lead to dissociation of the ligand from $\mathrm{T} 2 \mathrm{Cu}$ site $(\mathrm{Cu}-\mathrm{N}, \mathrm{Cu}-\mathrm{O}$ distances $>3.57 \AA)$ or a reverse side-on bound $\mathrm{HNO}_{2}$; these structures are provided in the Figure S5. 


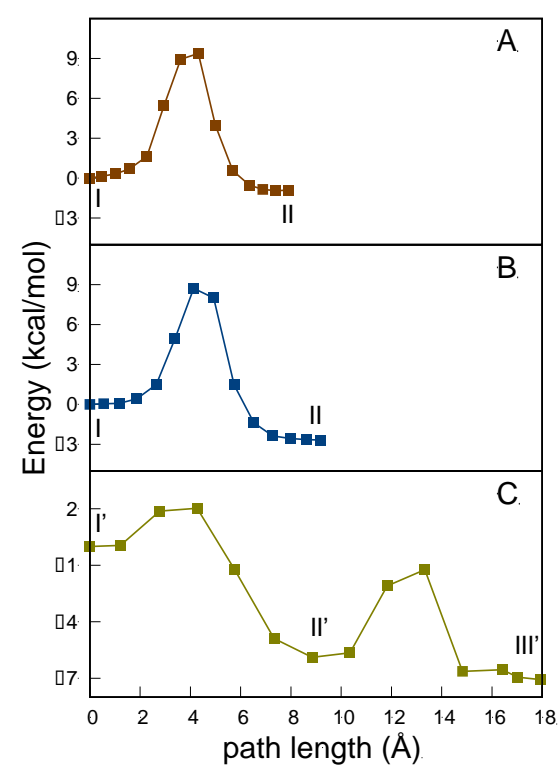

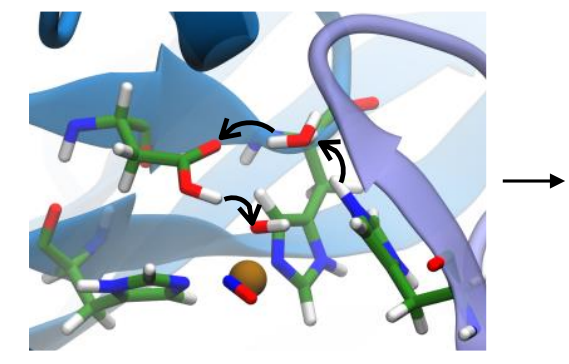

I; $\mathrm{NO}, \mathrm{OH}$ - bound

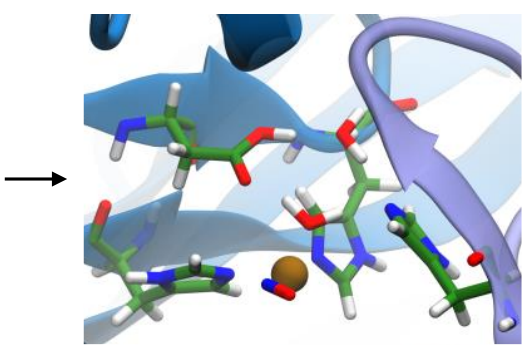

II; $\mathrm{NO}, \mathrm{H}_{2} \mathrm{O}$ bound

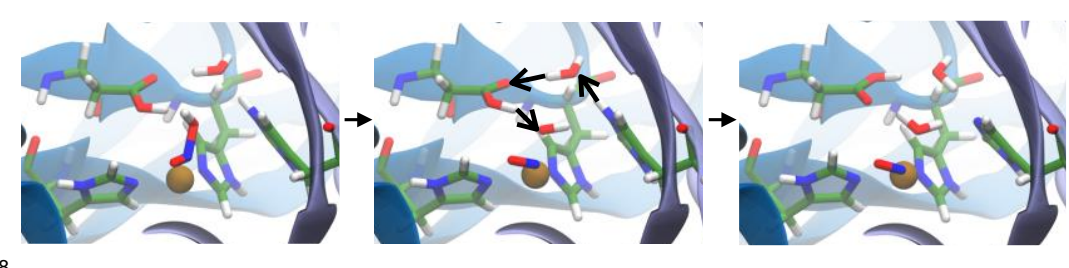

I'; $\mathrm{HNO}_{2}$ bound II'; $\mathrm{NO}, \mathrm{OH}$ - bound

Figure S4. CI-NEB pathways associated with the relay of protons from $\mathrm{HiscAT}_{\mathrm{CAT}} \mathrm{OH}^{-}$in the $\mathrm{NO}$, $\mathrm{OH}$ intermediate (I) via Asp $\mathrm{CAT}$ to form $\mathrm{NO}$ and $\mathrm{H}_{2} \mathrm{O}$ intermediate (II) at the T2Cu site. (A) depicts the pathway starting from $\mathrm{I}$, which was generated by barrierless scission of side-on bound $\mathrm{Cu}(\mathrm{I})-$ $\mathrm{NO}_{2}{ }^{-}$on proton transfer; (B) depicts the same pathway generated from reverse side-on bound $\mathrm{NO}_{2}{ }^{-}$ after barrierless scission of side-on bound $\mathrm{Cu}(\mathrm{I})-\mathrm{NO}_{2}{ }^{-}$on proton transfer. See Figure $\mathrm{S} 2$ for the $\mathrm{NO}_{2}$-intermediates. (C) The same CI-NEB pathway starting from an $\mathrm{HNO}_{2}$ intermediate formed on proton transfer to N-bound $\mathrm{Cu}(\mathrm{I})-\mathrm{NO}_{2}^{-}$(I') followed by $\mathrm{NO}, \mathrm{OH}^{-}$bound intermediate (II') and then the relay of protons from HisCAT to $\mathrm{OH}^{-}$via Aspcat to form $\mathrm{NO}$ and $\mathrm{H}_{2} \mathrm{O}$ (III').

A

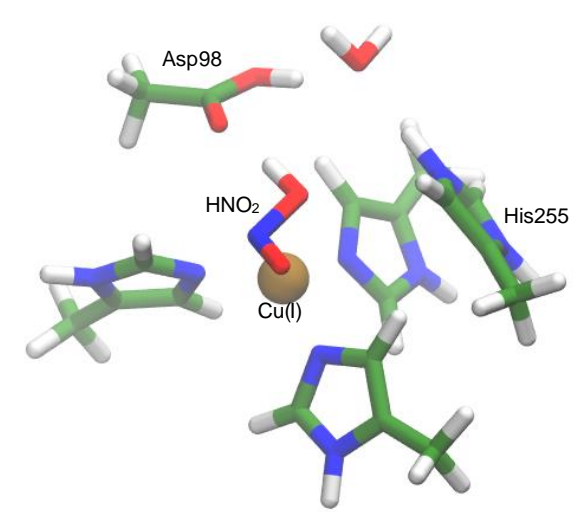

B

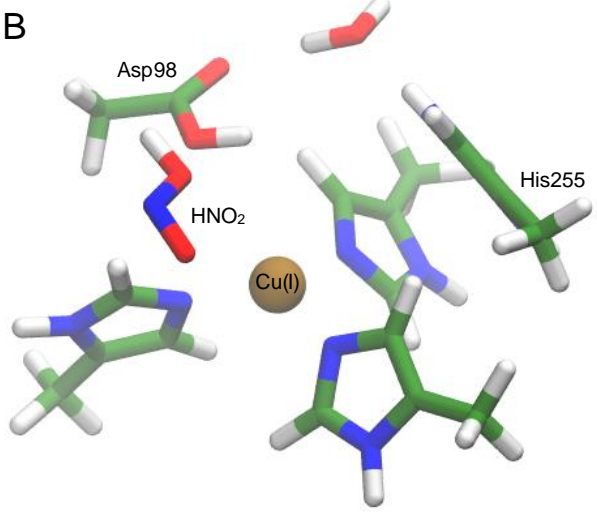

Figure S5. Proton transfer to the monodentate top-hat $\mathrm{Cu}(\mathrm{I})-\mathrm{NO}_{2}{ }^{-}$intermediate generating (A) reverse side-on bound $\mathrm{HNO}_{2}$ and (B) $\mathrm{HNO}_{2}$ dissociated from the T2Cu site. A subset of active site residues are shown in the QM region for clarity. 
Table S5. Geometrical parameters for $\mathrm{NO}_{2}^{-}$bound to $\mathrm{T} 2 \mathrm{Cu}$ in both oxidised $\mathrm{Cu}(\mathrm{II})$ and reduced $\mathrm{Cu}(\mathrm{I})$ state. These are $\mathrm{QM} / \mathrm{MM}$ optimisations performed on selected snapshots from MD trajectory of solvated Asp98p-Hsp system. See section 4.3 in the manuscript.

\begin{tabular}{|c|c|c|c|}
\hline \multicolumn{4}{|l|}{ Asp98p-Hsp System } \\
\hline Snapshot Description & $\begin{array}{l}\text { Distances }(\AA) \\
\mathrm{Cu}-\mathrm{N}, \quad \mathrm{Cu}-\mathrm{O} 1, \\
\mathrm{Cu}-\mathrm{O} 2\end{array}$ & $\begin{array}{ll}\theta, & \psi \\
\text { (degrees) } & \end{array}$ & Orientation \\
\hline \multicolumn{4}{|l|}{$\mathrm{Cu}(\mathrm{II})$} \\
\hline $\begin{array}{l}\text { No water interacting at the } \\
\text { active site }\end{array}$ & $2.67,2.06,2.43$ & $178.7,169.6$ & Bidentate top-hat \\
\hline Water interacting with Asp ${ }_{\mathrm{CAT}}$ & $2.66,2.05,2.42$ & $178.8,169.6$ & Bidentate top-hat \\
\hline Water interacting with $\mathrm{NO}_{2}^{-}$ & $2.64,2.03,2.40$ & $177.5,169.8$ & Bidentate top-hat \\
\hline $\begin{array}{l}\text { Water interacting with both } \\
\mathrm{NO}_{2}^{-} \text {and Asp }\end{array}$ & $2.65,2.03,2.42$ & $176.0,169.2$ & $\begin{array}{l}\text { Bidentate/Monodentate } \\
\text { top-hat }\end{array}$ \\
\hline HisCAT $\mathrm{H}$-bonded to $\mathrm{NO}_{2}^{-}$ & $2.65,2.06,2.38$ & $179.4,170.6$ & Bidentate top-hat \\
\hline $\begin{array}{l}\text { HisCAT and Ile } 257 \text { orientations } \\
\text { closest to the crystal structure }\end{array}$ & $2.62,2.05,2.36$ & $175.1,171.0$ & Bidentate top-hat \\
\hline \multicolumn{4}{|l|}{$\mathrm{Cu}(\mathrm{I})^{*}$} \\
\hline $\begin{array}{l}\text { No water interacting at the } \\
\text { active site }\end{array}$ & $2.82,3.27,2.44$ & $99.6,-$ & Reverse side-on ${ }^{\dagger}$ \\
\hline Water interacting with Asp ${ }_{\mathrm{CAT}}$ & $2.97,3.16,2.19$ & $142.0,146.9$ & $\begin{array}{l}\text { Between monodentate } \\
\text { top-hat and reverse side- } \\
\text { on }\end{array}$ \\
\hline Water interacting with $\mathrm{NO}_{2}^{-}$ & $2.90,3.16,2.29$ & $122.8,141.6$ & $\begin{array}{l}\text { Between monodentate } \\
\text { top-hat and reverse side- } \\
\text { on }\end{array}$ \\
\hline $\begin{array}{l}\text { Water interacting with both } \\
\mathrm{NO}_{2}^{-} \text {and Asp }{ }_{\mathrm{CAT}}\end{array}$ & $2.88,3.17,2.32$ & $117.5,137.2$ & $\begin{array}{l}\text { Between monodentate } \\
\text { top-hat and reverse side- } \\
\text { on }\end{array}$ \\
\hline HisCAT $\mathrm{H}$-bonded to $\mathrm{NO}_{2}^{-}$ & $2.75,3.27,2.51$ & $89.9,-$ & Reverse side-on \\
\hline $\begin{array}{l}\text { HisCAT and Ile } 257 \text { orientations } \\
\text { closest to the crystal structure }\end{array}$ & $2.80,3.32,2.23$ & $105.9,-$ & Reverse side-on \\
\hline
\end{tabular}

* The distances imply that though the orientation could be reverse side-on, the $\mathrm{NO}_{2}{ }^{-}$ion is significantly displaced as the $\mathrm{N}$ and $\mathrm{O}$ atoms are not equidistant from $\mathrm{Cu}$ as seen for experimental side-on orientation.

${ }^{\dagger}$ Reverse side-on is not obvious from the value of $\theta$, as it can indicate either side-on or reverse side-on. Reverse side-on was assigned in relation to surrounding amino acid residues by visual inspection. 
Table S6. The B3LYP-D3/def2-TZVP(Cu):def2-SVP(all):CHARMM QM/MM energies (absolute and relative) and geometric parameters for the optimised $\mathrm{Cu}(\mathrm{I})-\mathrm{NO}_{2}{ }^{-}$intermediates on the 3 subunits (A, B, C) of the chosen snapshot (i) discussed in the manuscript. The relative energies of the intermediates are calculated with respect to the monodentate top-hat intermediate.

\begin{tabular}{|l|l|l|l|l|}
\hline $\begin{array}{l}\mathrm{Cu}(\mathrm{I}) \\
\text { intermediates }\end{array}$ & $\begin{array}{l}\text { QM/MM } \\
\text { energy } \\
\text { (Hartree) }\end{array}$ & $\Delta \mathrm{E}(\mathrm{kcal} / \mathrm{mol})$ & $\begin{array}{l}\text { Distances }(\AA) \\
\text { Cu-N, Cu-O1, } \\
\text { Cu-O2 }\end{array}$ & $\theta, \psi($ degrees $)$ \\
\hline Chain A & -3483.559370 & 0.0 & $2.91,2.31,2.75$ & $155.1,164.3$ \\
\hline $\begin{array}{l}\text { Monodentate } \\
\text { top-hat }\end{array}$ & -3483.566236 & -4.3 & $2.75,3.36,2.38$ & $91.3, \mathrm{n} / \mathrm{a}$ \\
\hline Side-on & -3483.567723 & -5.2 & $2.05,2.89,2.83$ & $22.0,4.8$ \\
\hline N-Bound & -3483.566550 & -4.5 & $2.81,3.23,2.72$ & $88.4, \mathrm{n} / \mathrm{a}$ \\
\hline Reverse side-on & & & & \\
\hline Chain B & -3483.513004 & 0.0 & $2.87,2.72,2.22$ & $160.4,163.5$ \\
\hline $\begin{array}{l}\text { Monodentate } \\
\text { top-hat }\end{array}$ & -3483.515616 & -1.6 & $2.77,3.36,2.33$ & $95.3, \mathrm{n} / \mathrm{a}$ \\
\hline Side-on & -3483.519854 & -4.3 & $2.01,2.85,2.83$ & $18.9,3.8$ \\
\hline N-Bound & -3483.516704 & -2.3 & $2.84,3.28,2.46$ & $100.5, \mathrm{n} / \mathrm{a}$ \\
\hline Reverse side-on & & & $2.84,2.16,2.68$ & $167.1,164.3$ \\
\hline Chain C & -3559.800752 & 0.0 & $2.76,3.10,2.36$ & $108.9, \mathrm{n} / \mathrm{a}$ \\
\hline $\begin{array}{l}\text { Monodentate } \\
\text { top-hat }\end{array}$ & & -1.2 & $1.97,2.83,2.83$ & $10.1,1.9$ \\
\hline Side-on & -3559.802681 & $-8.63,3.15,2.31$ & $94.1, \mathrm{n} / \mathrm{a}$ \\
\hline N-Bound & -3559.814305 & -8.5 & -6.4 & \\
\hline Reverse side-on & -3559.810958 & & & \\
\hline
\end{tabular}



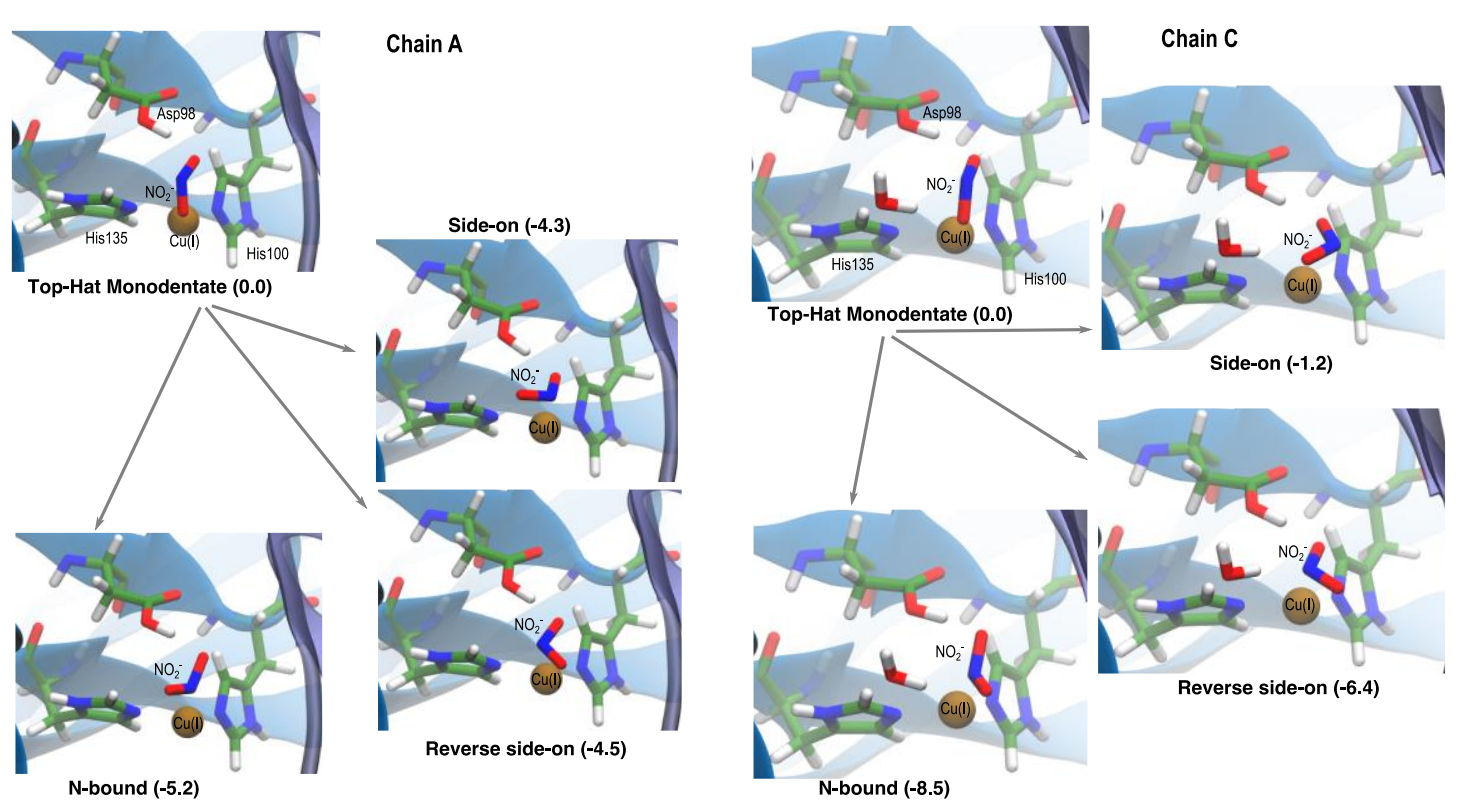

Figure S6. All the intermediates observed with $\mathrm{NO}_{2}{ }^{-}$bound to reduced $\mathrm{Cu}(\mathrm{I})$ in Chain $\mathrm{A}$ and Chain $\mathrm{C}$ of the $\mathrm{T} 2 \mathrm{Cu}$ unit in solvated $A c \mathrm{NiR}$ for the chosen snapshot (i) described in the manuscript (Figure 9 of the manuscript provides the one corresponding to Chain B). The energies in $\mathrm{kcal} / \mathrm{mol}$ relative to the $\mathrm{Cu}(\mathrm{I})$ top-hat monodentate calculation are given in parentheses.
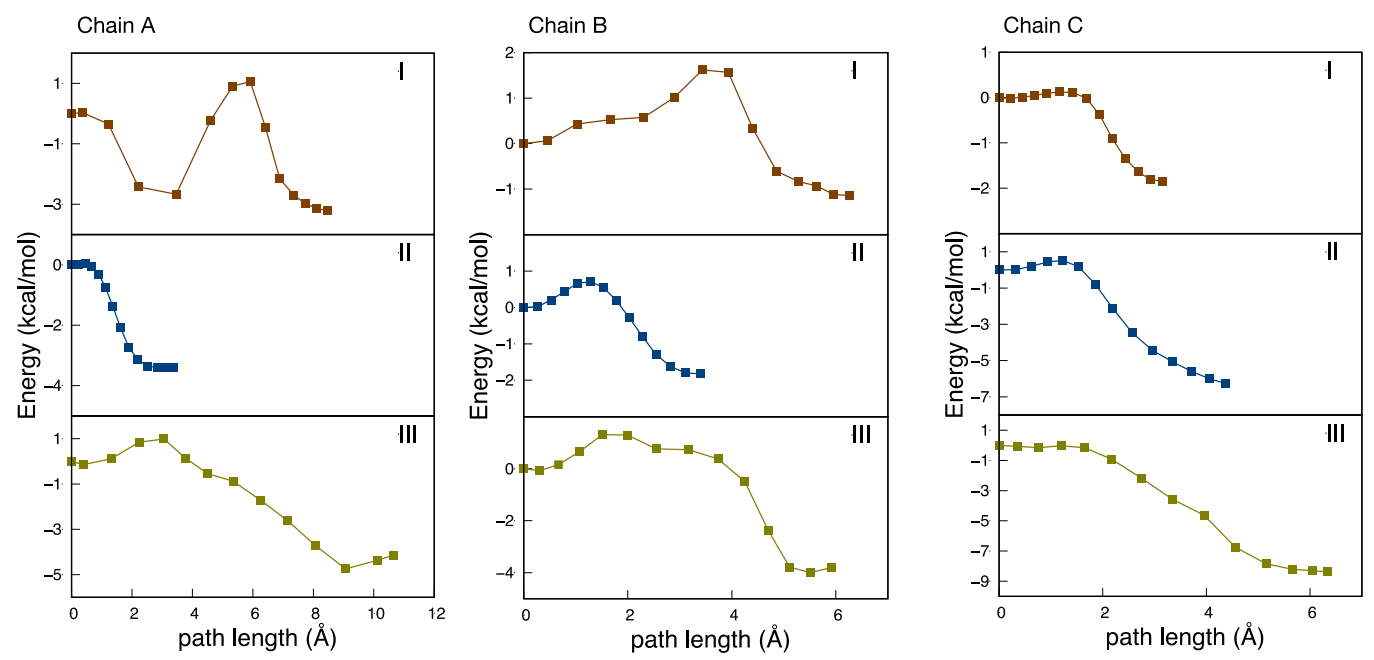

Figure S7. CI-NEB profiles for conversion of $\mathrm{Cu}(\mathrm{I})$ monodentate top-hat $\mathrm{NO}_{2}{ }^{-}$intermediate to (I) side-on, (II) reverse side-on and (III) N-bound intermediates for Chain A, B and C of the selected snapshot (i) described in the manuscript. The N-bound intermediate is the lowest energy structure for all 3 chains, and as for the crystal system, the side-on orientation is an intermediate along the pathway to N-bound in chain $\mathrm{A}$ and $\mathrm{B}$. In chain $\mathrm{C}$ however, the reverse side-on is the observed intermediate along the N-bound pathway. In chain A, the pathway to form side-on involves an initial transformation to reverse side-on followed by transformation of the reverse side-on to sideon via a monodentate orientation which is metastable and couldn't be isolated. 
Table S7. Geometrical parameters for $\mathrm{NO}_{2}^{-}$bound to $\mathrm{T} 2 \mathrm{Cu}$ in both oxidised $\mathrm{Cu}(\mathrm{II})$ and reduced $\mathrm{Cu}(\mathrm{I})$ state from selected snapshots of the MD trajectory of the solvated Asp98p-Hsd and Asp98Hsp systems.

\begin{tabular}{|c|c|c|c|}
\hline \multicolumn{4}{|c|}{ Asp98p-Hsd System } \\
\hline & $\begin{array}{l}\text { Distances }(\AA) \\
\mathrm{Cu}-\mathrm{N}, \quad \mathrm{Cu}-\mathrm{O} 1, \\
\mathrm{Cu}-\mathrm{O} 2\end{array}$ & $\begin{array}{l}\theta, \\
\text { (degrees) }\end{array}$ & Orientation $^{\dagger}$ \\
\hline \multicolumn{4}{|l|}{$\mathrm{Cu}(\mathrm{II})$} \\
\hline Snapshot 1 & $2.62,2.01,2.38$ & $173.2,170.5$ & Bidentate top-hat \\
\hline Snapshot 2 & $2.61,2.03,2.34$ & $176.0,171.5$ & Bidentate top-hat \\
\hline Snapshot 3 & $2.65,2.01,2.45$ & $179.1,168.4$ & Bidentate/Monodentate top-hat \\
\hline Snapshot 4 & $2.64,2.01,2.44$ & $176.4,168.5$ & Bidentate/Monodentate top-hat \\
\hline Snapshot 5 & $2.58,2.02,2.30$ & $179.7,174.4$ & Bidentate top-hat \\
\hline Snapshot 6 & $2.65,2.04,2.42$ & $179.1,171.2$ & Bidentate top-hat \\
\hline \multicolumn{4}{|l|}{$\mathbf{C u}(\mathbf{I})^{*}$} \\
\hline Snapshot 1 & $2.96,3.08,2.16$ & $1453,152.2$ & Between monodentate top-hat and reverse side-on \\
\hline Snapshot 2 & $2.98,3.19,2.14$ & $141.1,147.4$ & Between monodentate top-hat and reverse side-on \\
\hline Snapshot 3 & $2.90,3.16,2.29$ & $111.3,124.0$ & Between monodentate top-hat and reverse side-on \\
\hline Snapshot 4 & $2.97,2.99,2.10$ & $168.0,156.9$ & Between monodentate top-hat and reverse side-on \\
\hline Snapshot 5 & $2.85,2.81,2.09$ & $169.0,160.5$ & Monodentate top-hat \\
\hline Snapshot 6 & $2.98,3.05,2.10$ & $175.2,153.5$ & Monodentate top-hat \\
\hline \multicolumn{4}{|c|}{ Asp98-Hsp System } \\
\hline \multicolumn{4}{|c|}{$\mathrm{Cu}(\mathrm{II})$} \\
\hline Snapshot 1 & $2.62,2.03,2.37$ & $179.8,171.7$ & Bidentate top-hat \\
\hline Snapshot 2 & $2.62,2.05,2.35$ & $179.0,172.7$ & Bidentate top-hat \\
\hline Snapshot 3 & $2.62,2.07,2.34$ & $176.7,173.3$ & Bidentate top-hat \\
\hline Snapshot 4 & $2.65,2.08,2.38$ & $177.5,172.3$ & Bidentate top-hat \\
\hline Snapshot 5 & $2.59,2.00,2.37$ & $179.6,170.9$ & Bidentate top-hat \\
\hline Snapshot 6 & $2.63,2.06,2.36$ & $179.5,172.5$ & Bidentate top-hat \\
\hline \multicolumn{4}{|l|}{$\mathbf{C u}(\mathbf{I})$} \\
\hline Snapshot 1 & $2.86,2.80,2.14$ & $165.7,163.6$ & Between monodentate top-hat and reverse side-on \\
\hline Snapshot 2 & $3.00,3.48,2.25$ & $116.7,112.2$ & Between monodentate top-hat and reverse side-on \\
\hline Snapshot 3 & $2.98,3.05,2.08$ & $174.9,153.8$ & Monodentate top-hat \\
\hline Snapshot 4 & $3.11,3.29,2.10$ & $173.5,148.4$ & Monodentate top-hat \\
\hline Snapshot 5 & $2.96,3.65,2.29$ & $98.4,-$ & Reverse side-on \\
\hline Snapshot 6 & $2.96,3.53,2.30$ & $106.5,-$ & Reverse side-on \\
\hline
\end{tabular}

* The distances implies that though the orientation could be reverse side-on, the $\mathrm{NO}_{2}{ }^{-}$is quite displaced as the $\mathrm{N}$ and $\mathrm{O}$ atoms are not equidistant from $\mathrm{Cu}$ as seen for experimental side-on orientation.

${ }^{\dagger}$ Reverse side-on is not obvious from the value of $\theta$, as it can indicate either side-on or reverse side-on. Reverse side-on was assigned in relation to surrounding amino acid residues by visual inspection. 

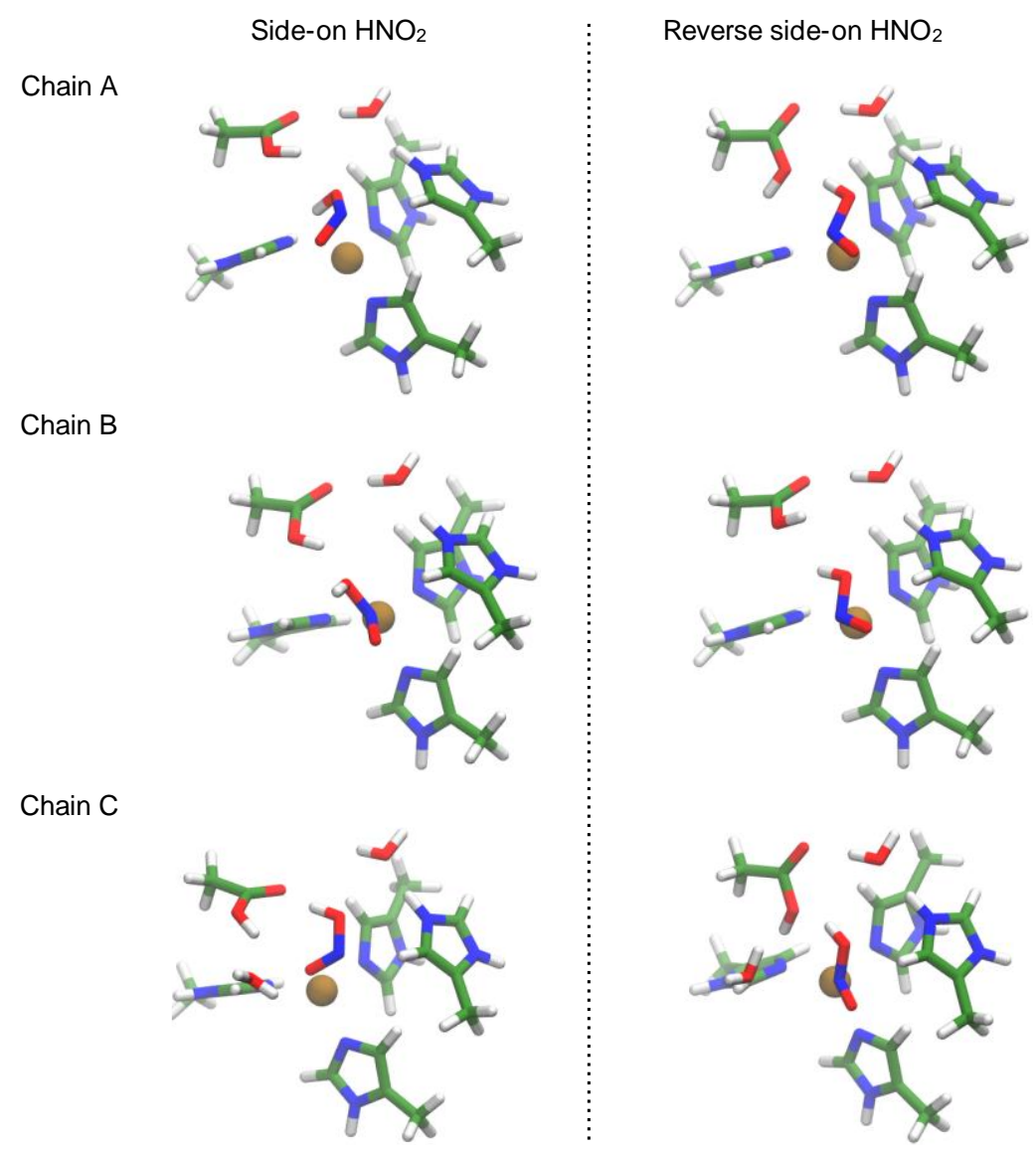

Monodentate top-hat $\mathrm{HNO}_{2}$
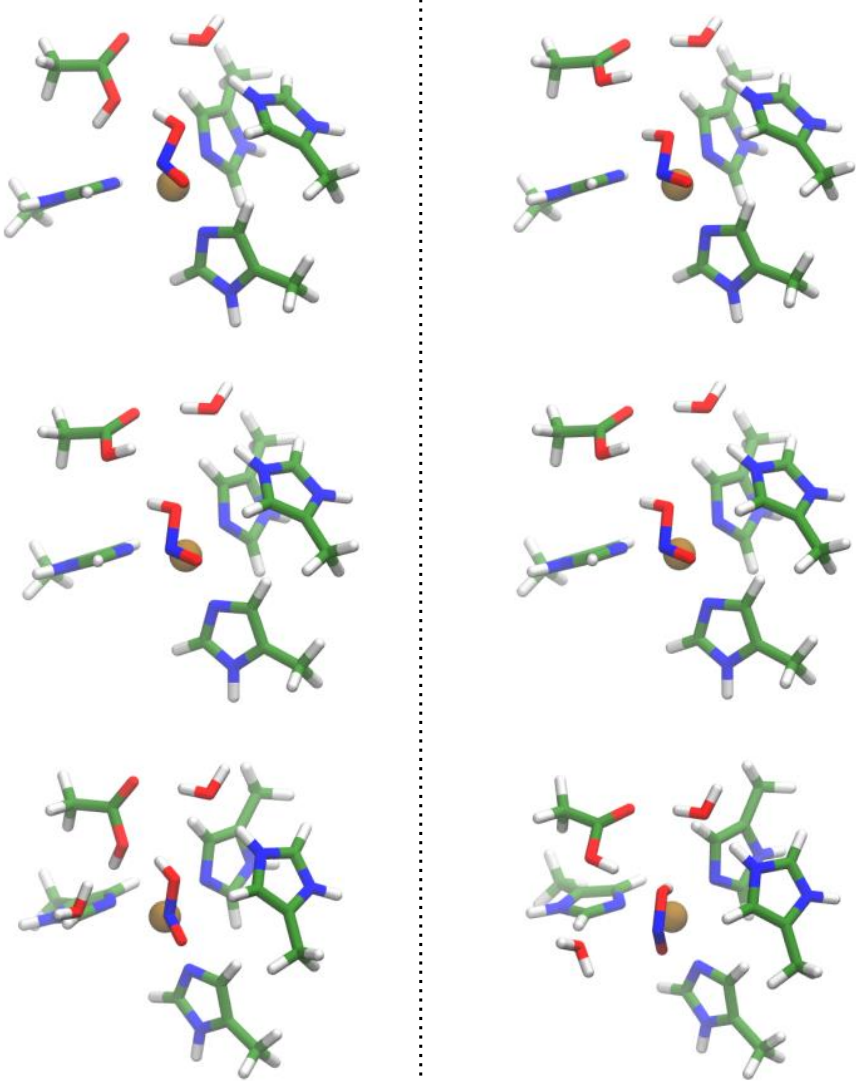

Figure S8. $\mathrm{HNO}_{2}$ intermediates formed from side-on, reverse side-on and monodentate top-hat $\mathrm{NO}_{2}{ }^{-} \mathrm{Cu}(\mathrm{I})$ intermediates on proton transfer. A subset of active site residues are shown in the QM region for clarity.

\section{Reference}

(1) Sen, K.; Hough, M. A.; Strange, R. W.; Yong, C. W.; Keal, T. W. A QM/MM Study of Nitrite Binding Modes in a Three-Domain Heme-Cu Nitrite Reductase. Molecules 2018, 23, 2997. 